\title{
Analysing the characteristics of soil nematode communities at pepper (Piper nigrum L.) culti- vation area in Loc Hung commune, Loc Ninh district, Binh Phuoc province
}

\author{
Phân tích đặc trung quần xã tuyến trùng đất tại vùng trồng hồ tiêu \\ (piper nigrum L.) thuộc xã Lộc Hung, huyện Lộc Ninh, tỉnh Bình Phuớc \\ Research article
}

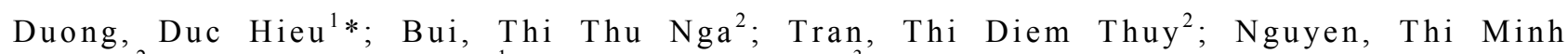
Phuong ${ }^{2}$; Nguyen, Huu Hung ${ }^{1}$; Nguyen, Vu Thanh ${ }^{3}$

${ }^{1}$ Institute of Tropical Biology, Vietnam Academy of Science and Technology (VAST). 9/621 Hanoi highway, Linh Trung ward, Thu Duc district, HCM city, Vietnam; ${ }^{2}$ University of Science, Vietnam National University of Ho Chi Minh City; ${ }^{3}$ Institute of Ecology and Biology Resources, VAST. 18 Hoang Quoc Viet, Cau Giay, Hanoi, Vietnam

\begin{abstract}
Pepper (Piper nigrum L.) is a high economic value plant species that brings the main income to the people at Loc Hung commune. So the pepper's yield plays a significant role in people's life in this region. To assess the influence of environmental factors on the growth and development of pepper, we need to analyse the structural characteristics of soil nematode communities in order to promptly detect the levels of parasitic nematodes infection as well as assessment of soil environment status based on nematode communities. Study results at five sampling stations are analyses of 30 genera of nematodes belonging to 6 major trophic groups (bacterial feeders, fungal feeders, algal feeders, omnivores, carnivores and plant parasites). Calculation results of indices such as $\Sigma \mathrm{MI}$, $\Sigma$ MI2-5, MI and PPI showed that soil nematodes community is very little affected by the bacteria feeder group and the rate of parasitic nematode pepper quite severe. Analysis of correlation between trophic groups showed that nematodes are sensitive to environmental factors. This means the potential use of nematodes as a biological indicator for soil quality is possible.

Hồ tiêu (Piper nigrum L.) là cây trồng có giá trị kinh tế cao và là nguồn thu nhập chính của người dân tại xã Lộc Hung. Do đó, năng suất cây tiêu có ý nghĩa rất lớn đối với đời sống người dân trong vùng. Để đánh giá ảnh huơong của các yếu tố môi truờng lên sự sinh trương và phát triển của cây tiêu, cần phải phân tích đặc trung cấu trúc quần xã tuyến trùng đất của vùng nhằm phát hiện kịp thời mức độ nhiếm tuyến trùng ký sinh trên hồ tiêu cũng nhu đánh giá nhanh hiện trạng môi truờng đất dựa trên quần xã tuyến trùng. Kết quả nghiên cứu tại 5 điểm thu mẫu phân tích được 30 giống tuyến trùng thuộc 6 nhóm dinh duỡng chính (ăn vi khuẩn, ăn nấm, ăn tảo, ăn tạp, ăn thịt và ký sinh thục vật). Kết quả tính toán các chỉ số $\sum M I, \sum M I 2-5$, MI và PPI cho thấy quần xã tuyến trùng đất ở đây rất ít chịu ảnh hương của nhóm ăn vi khuẩn và tỷ lệ hồ tiêu nhiếm ký sinh khá nặng. Phân tích tương quan giũa các nhóm dinh duõng cho thấy tuyến trùng khá nhạy cảm với các yếu tố môi truòng, điều này cho thấy tiềm năng sử dụng tuyến trùng nhu một sinh vật chỉ thị cho chất lượng môi trường đất.
\end{abstract}

Keywords: correlation, biological indicators, nematodes, pepper, Loc Hung, Binh Phuoc

\section{Introduction}

Nematodes are an invertebrate group that has great potential in the use as indicator organisms for soil quality. Nematodes possess the most important attributes of any prospective bio-indicator (Cairns et al., 1993): abundance in virtually all environments, diversity of life strategies and feeding habits (Freckman, 1988; Yeates et al., 1993a), 
short life cycles, and relatively well-defined sampling procedures. Therefore, nematode community structure will reflect the differences of environmental quality. The environmental factors will impact on the nematode groups in soil and change the proportion of these groups to respond with disturbances. Conventional farming systems have been associated with many environmental risks, so the ability to monitor and assess the quality of soil agroecosystem would be of significant importance. The idea that changes in the soil environment imposed by agricultural management practices could be revealed by measures of nematode community patterns has been investigated in recent years (Ferris et al., 1996; Freckman and Ettema, 1993; Yeates et al., 1997; Nguyen Ngoc Chau and Nguyen Vu Thanh, 2005; Duong Duc Hieu et al., 2009).

For these reasons, several researchers have attempted to develop relationships between nematode community structure and succession of natural ecosystems or environmental disturbance (Ettema and Bongers, 1993; Freckman and Ettema, 1993; Freckman and Virginia, 1997; Wasilewska, 1994; Yeates and Bird, 1994). Thus, it is important to find trends illustrating the soil condition, but more important to find their explanation.

For pepper cultivation area in Loc Hung - Binh Phuoc province, the soil nematode community structure will reflect characterized farming and environmental status of the land. Besides, pepper parasitic nematodes cause loss of economic. Therefore, analysing community structure to assess parasitic level and environmental status of land in the study area is important to give methods to minimize the effects of parasitic nematodes and to give appropriate cultivation methods to improve plant productivity without causing degradation of land environment.

\section{Location, materials and methods}

\subsection{Location}

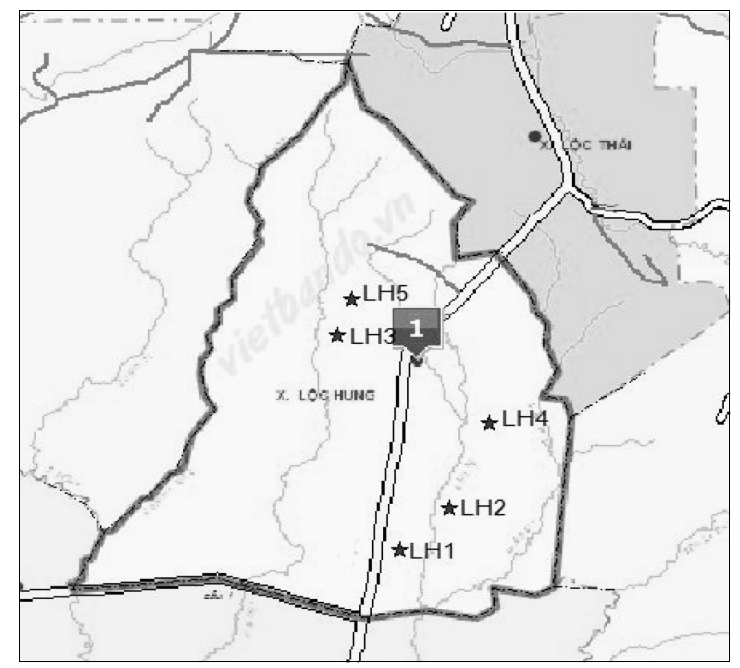

Figure 1. The sampling stations map in Loc Hung (Binh Phuoc province)

Loc Hung commune (Loc Ninh district, Binh Phuoc province) locates in the south of Vietnam and near Ho Chi Minh city. We used GPS to determine the coordinates of sampling points (Table 1) and used MapInfo 9.0 software to build the diagram sampling position (Figure 1).

Table 1. The coordinates of stations in Loc Hung

\begin{tabular}{ccc}
\multirow{2}{*}{ Stations } & \multicolumn{2}{c}{ Sample coordinates } \\
\cline { 2 - 3 } & North latitude & East longitude \\
\hline LH1 & $12^{0} 28^{\prime} 53,20^{\prime}$ & $106^{0} 39^{\prime} 37,90^{\prime \prime}$ \\
LH2 & $12^{0} 29^{\prime} 15,63^{\prime \prime}$ & $106^{0} 47^{\prime} 18,08^{\prime}$ \\
LH3 & $11^{0} 01^{\prime} 00,64^{\prime}$, & $106^{0} 21^{\prime} 19,48^{\prime}$ \\
LH4 & $12^{0} 45^{\prime} 01,06^{\prime \prime}$ & $106^{0} 51^{\prime} 49,41^{\prime}$ \\
LH5 & $12^{0} 06^{\prime} 06,08^{\prime}$, & $106^{0} 22^{\prime} 46,60^{\prime}$
\end{tabular}

\subsection{Materials and methods}

Surveying and sampling at 5 pepper farms on January, 2012. We randomly selected 3 pepper stumps from each farms, in each stump we collected 3 soil samples by using the method of Nguyen Ngoc Chau (2003): $30 \mathrm{~cm}$ out of stump, depth from $10-15 \mathrm{~cm}$, about 500 gram soil, then the samples were preserved in plastic bags. The total number of samples includes 15 soil samples that were respectively denoted LH1, LH2, LH3, LH4, and LH5. Sampling temperature was about $30-33^{\circ} \mathrm{C}$.

Nematodes were extracted from 100 gram soil each sample by decanting and centrifugation with sugar media (Nic Smol, 2007). After counting on the square counting dish, nematodes were picked up and mounted by Seinhorst's method (1959), then 200 individuals per site were randomly selected and identified to taxonomic genus according to Fauna in Vietnam (Nguyen Ngoc Chau and Nguyen Vu Thanh 2000; Nguyen Vu Thanh, 2007); Freshwater nematode: Ecology and Taxonomy (Abebe, E., et al., 2007); Aphelenchida, Longidoridae and Trichodoridae (Hunt, D.J., 1993).

Nematodes were classified as six trophic groups: bacterial feeders, fungal feeders, algal feeders, omnivores, carnivores and plant parasites. The classification of feeding groups mainly followed Yeates et al. (1993).

The determination of nematode types along the colonization-persistence gradient followed Bongers (1988; 1990), c-p index shows the sustainability level of ecosystems, it has value from 1 to 5 corresponding to the level from unstable (colonizers) to stable (persisters) of ecosystems. Nematode group with $\mathrm{cp}=1$ is high colonizable level, easy to change and consistent with an unsustainable environment; while nematode group with $\mathrm{cp}=5$ is a group of high settlement and indicates a sustainable environment.

The calculation of the maturity index MI and PPI followed Bongers (1990) and Tom Bongers and Howard Ferris (1999). MI or PPI $=\sum_{\mathrm{i}=1}^{\mathrm{n}} \mathrm{v}(\mathrm{i}) \mathrm{x} \mathrm{f}(\mathrm{i})$, where $\mathrm{v}(\mathrm{i})$ is the c-p value of taxon $i, f(i)$ is the frequency of taxon $i$ in a sample. Maturity Indices of nematode community calculated by formula include: $\sum \mathrm{MI}$ is total maturity index (including free-living nematodes and parasitic nematodes), $\sum$ MI2-5 is maturity index (except nematodes with 
$\mathrm{c}-\mathrm{p}=1), \mathrm{MI}$ is maturity index of free-living nematodes (not including plant parasitic nematode groups).

\section{Results and discussion}

\subsection{Nematode community structure in Loc Hung, Binh Phuoc province}

\subsubsection{Component trophic groups}

The analysis result of grouped nematode in 5 sampling points is shown in Table 2, c-p value for each genus is determined according to Bongers et al (1990).

At sampling point LH1, the result of analysis gained 19 genera. This was the sampling point having the highest number of genera (occurring $54.29 \%$ of total number of analysed genera). Therein, the dominant genera were Meloidogyne sp. (32.93\%) and Cephalobus sp. (14.63\%). Others occurred in a very low proportion (less than 6.5\%).
At sampling point $\mathrm{LH} 2$, the result of analysis gained 13 genera (occurring $37.14 \%$ of total number of analysed genera). The dominant genera were Helicotylenchus sp. $(31.97 \%)$, Filenchus sp. (23.13\%) và Meloidogyne sp. (13.86\%). Others were less than $9.0 \%$.

Another sampling point having high number of genera was LH3 with 17 genera (occurring $48.57 \%$ of total number of analysed genera). Therein, Meloidogyne sp. was the most dominant genus with $38.27 \%$ in total individuals. Others were less than $9.5 \%$.

The result of analysis at LH4 gained 15 genera (occurring $42.86 \%$ of total number of analysed genera). Specially, in this point, the extremely dominant genus was Meloidogyne sp. with $74.67 \%$ in total individuals, while the second dominant genus was only $8.44 \%$. Others were less than $6 \%$.

Table 2. Grouping of nematodes at the sampling points in Loc Hung, Binh Phuoc province

\begin{tabular}{|c|c|c|c|c|c|c|}
\hline \multirow{2}{*}{ Genus } & \multirow{2}{*}{$\begin{array}{l}\text { Trophic } \\
\text { groups }\end{array}$} & \multicolumn{5}{|c|}{ The sampling points } \\
\hline & & LH1 & LH2 & LH3 & LH4 & LH5 \\
\hline Cephalobus sp. & $\mathrm{Ba}_{2}$ & $* *$ & $*$ & $*$ & $*$ & $*$ \\
\hline Cryptonchus sp. & $\mathrm{Ba}_{3}$ & $*$ & & & & \\
\hline Eucephalobus sp. & $\mathrm{Ba}_{2}$ & $*$ & $*$ & $*$ & $*$ & \\
\hline Geomonhystera sp. & $\mathrm{Ba}_{2}$ & & & $*$ & & \\
\hline Heterocephalobus sp. & $\mathrm{Ba}_{2}$ & $*$ & $*$ & $*$ & $*$ & $*$ \\
\hline Panagrolaimus sp. & $\mathrm{Ba}_{1}$ & $*$ & $*$ & $*$ & $*$ & $*$ \\
\hline Prismatolaimus sp. & $\mathrm{Ba}_{3}$ & $*$ & $*$ & $*$ & $*$ & $*$ \\
\hline Protorhabditis sp. & $\mathrm{Ba}_{1}$ & & & & & $*$ \\
\hline Rhabditis sp. & $\mathrm{Ba}_{1}$ & $*$ & & & & $*$ \\
\hline Terschellingia sp. & $\mathrm{Ba}_{3}$ & & & & $*$ & \\
\hline Aphelenchoides sp. & $\mathrm{Fu}_{2}$ & $*$ & $*$ & & $*$ & $*$ \\
\hline Aphelenchus sp. & $\mathrm{Fu}_{2}$ & $*$ & & * & & \\
\hline Achromadora sp. & $\mathrm{Al}_{3}$ & & & * & $*$ & $*$ \\
\hline Actus sp. & $\mathrm{Ca}_{4}$ & $*$ & $*$ & & & \\
\hline Iotonchus sp. & $\mathrm{Ca}_{4}$ & $*$ & & & & \\
\hline Mylonchulus sp. & $\mathrm{Ca}_{4}$ & $*$ & & & $*$ & \\
\hline Aporcelaimus sp. & $\mathrm{Om}_{5}$ & & & $*$ & & \\
\hline Aporcelaimellus sp. & $\mathrm{Om}_{5}$ & $*$ & $*$ & * & $*$ & \\
\hline Crocodorylaimus sp. & $\mathrm{Om}_{4}$ & $*$ & & $* *$ & $*$ & $*$ \\
\hline Dorylaimoides sp. & $\mathrm{Om}_{3}$ & $*$ & & * & & $*$ \\
\hline Ischiodorylaimus sp. & $\mathrm{Om}_{4}$ & & & & $*$ & \\
\hline Mesodorylaimus sp. & $\mathrm{Om}_{4}$ & & & * & & \\
\hline Prodorylaimus sp. & $\mathrm{Om}_{4}$ & & & $*$ & & \\
\hline Aglenchus sp. & $\mathrm{H}_{2}$ & & $*$ & & & \\
\hline Filenchus sp. & $\mathrm{H}_{2}$ & $*$ & $* *$ & $*$ & & $*$ \\
\hline Helicotylenchus sp. & $\mathrm{H}_{3}$ & & $* *$ & & $*$ & \\
\hline Hoplolaimus sp. & $\mathrm{H}_{3}$ & $*$ & & & & \\
\hline Meloidogyne sp. & $\mathrm{H}_{3}$ & $* *$ & $* *$ & $* *$ & $* * *$ & $* * *$ \\
\hline
\end{tabular}


Rotylenchulus sp.

$\mathrm{H}_{3}$

Xiphinema sp.

*: $<10 \% ; \quad * *: 10-50 \% ; \quad * * *:>50 \%$

${ }^{I}$ Nematodes were divided into different groups depending on trophic characteristics and their life cycle. Symbol: $A_{x}$ (with A: trophic group, x: c-p value); Ba: Bacterivores; Fu: Fungivores; Al: Algivores; Ca: Carnivores; Om: Omnivores; $H$ : Herbivores.

The last sampling point was LH5 having 13 genera (occurring $37.14 \%$ of total number of analysed genera). The same to LH4, the extremely dominant genus at LH5 was Meloidogyne sp. with $76.22 \%$ in total individuals, while the second dominant genus was only $8.39 \%$. Others were less than $6 \%$.

The above results showed that Meloidogyne sp. - nematode genus was parasitic on pepper roots and was pestiferous for pepper - was the genus presenting in all of the sampling points with a very high percentage. Thus, the plant parasitic group of nematode was dominant in nematode community and they reflected the feature of region.

\subsubsection{Proportion of trophic groups in Loc Hung}

Analysis result of nematode community structure in Loc Hung gained 30 genera of six major trophic groups including: 7 genera of plant parasitic group (accounting for $55.19 \%$ of individuals), 10 genera of bacterivorous group (accounting for $29.67 \%$ of individuals), 7 genera of omnivorous group (accounting for $10.20 \%$ of total individuals), 2 genera of fungivorous group (accounting for $2.96 \%$ of total individuals), 3 genera of carnivorous group (accounting for $1.65 \%$ of total individuals) and 1 genus of algivorous group (accounting for $0.32 \%$ of total individual) as shown in Figure 2.

We can see that bacterivorous group and plant parasitic group are the dominant groups at most of sampling points (especially plant parasitic group), followed by omnivorous group, other groups occupy a negligible proportion. This rate reflects characteristics of the agricultural area. In this ecosystem, the use of fertilizers always leads to the significant increase of bacterivorous group and plant parasitic group. The rate of parasitic nematodes in the studied area is very high, this show that peppers in Loc Hung are infected parasitic nematodes seriously.

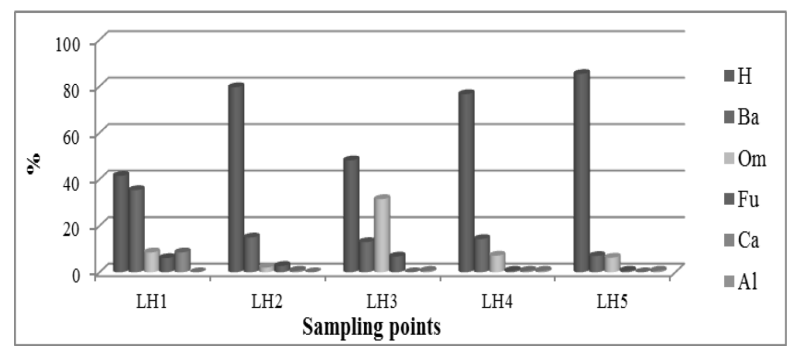

Figure 2. Percentage of nematode groups in the sampling points

Percentage of the nematode groups also shows that the carnivorous group in Loc Hung is very low; it is similar with the study result of Arantzazu Urzelai (2000), he showed that the carnivorous group was the nematode group less abundant in ecosystem types. This stems from ecological characteristics of the carnivorous group, they have a long lifecycle, low metabolic activity, slow fertility, so they have small number and low frequency.

\subsubsection{Gender structure}

Gender percentage at the sampling points on Figure 3 shows that the number of juvenile individuals presents with very high rates in comparison to females and males. The general trend on farms is the dominance of juveniles, and the rate of females is almost higher than males but both of them are lower than juveniles.

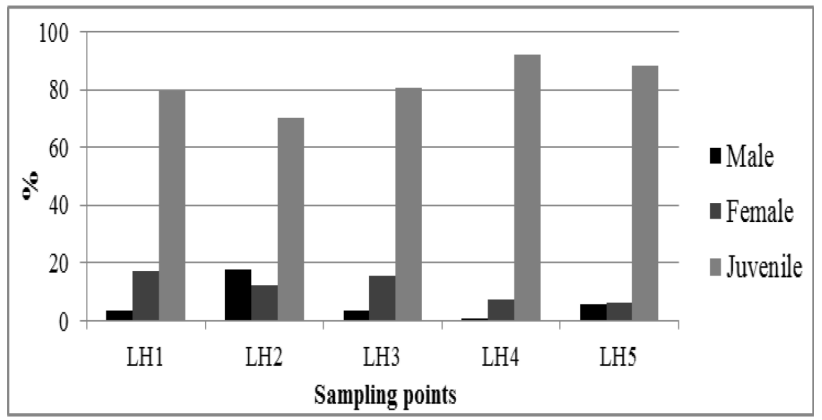

Figure 3. Gender structure at the sampling points

The presence of many juveniles shows that nematode community in the studied area is in the reproductive period and increases the number strongly.

For some of genera such as Itonchus sp., Hoplolaimus sp., Ischiodorylaimus sp., Mylonchulus sp., Prodorylaimus sp. we didn't detect the occurrence of juveniles. May be this isn't their reproductive stage, and from the dominant presence of females in some genera can predict nematode density in these genera will increase when environmental conditions are appropriate.

For nematodes, the asexual and sexual reproductive forms may occur on a genus. Therefore, in asexual reproduction genera, males rarely appear. This can explain for the low frequency of males, even not found (Randy and Anwar, 2004). However, the distribution process and structure formation are affected by many environmental factors and living conditions. In general, gender structure in the studied area with great frequency of juveniles in most of genera showed that soil environmental condition is favorable for the growth and development of nematode community.

\subsection{The relationship between ecological indi- ces}

To assess infested level of pepper as well as assess status of soil environment in Loc Hung through their relationship, we used the ecological indices such as PPI and vari- 
ous maturity indices ( $\Sigma \mathrm{MI}, \Sigma \mathrm{MI}-5$ and MI). Calculated results of ecological indices are shown on table 3 .

Table 3. Ecological indices of nematode community in Loc Hung

\begin{tabular}{cccccc} 
Index & LH1 & LH2 & LH3 & LH4 & LH5 \\
\hline$\Sigma$ MI & 2.56 & 2.60 & 3.06 & 2.97 & 2.90 \\
PPI & 1.07 & 2.14 & 1.36 & 2.30 & 2.49 \\
PPI/ $\mathbf{L I}$ & 0.40 & 0.82 & 0.45 & 0.77 & 0.86 \\
$\Sigma$ MI2-5 & 2.49 & 2.58 & 3.05 & 2.96 & 2.87 \\
MI & 1.49 & 0.47 & 1.70 & 0.67 & 0.41
\end{tabular}

The relationship between ecological indicators calculated in Table 3 is shown on Figure 4 and Figure 5.

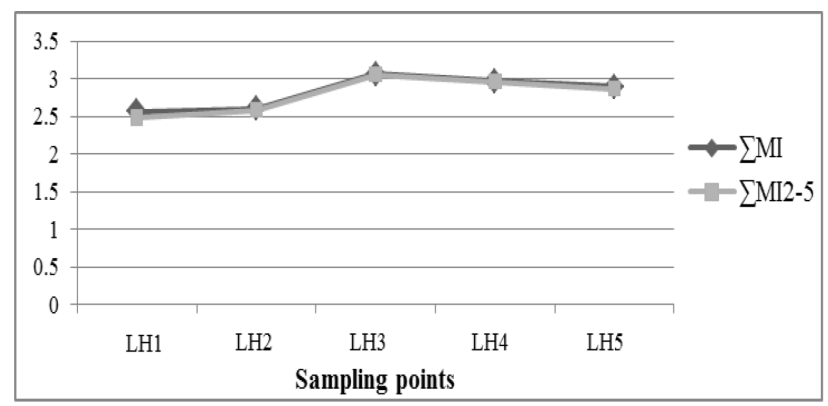

Figure 4. The relationship between $\Sigma$ MI and $\Sigma$ MI2-5

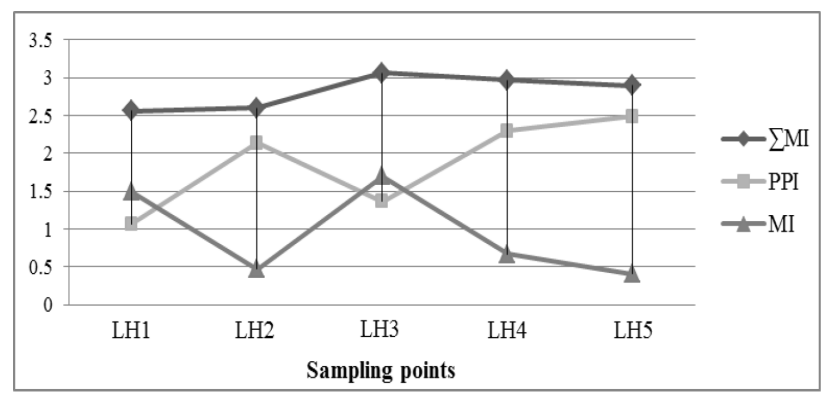

Figure 5. The relationship between $\Sigma$ MI, PPI and MI

Curve that performs the relationship between $\Sigma$ MI and $\Sigma$ MI2-5 shows effect of bacterivorous group with $\mathrm{cp}=1$ negligible. The maturity index of nematode community in the sampling points was hardly influenced from the nematode group with $\mathrm{cp}=1$. Due to the ecological characteristic of nematodes group with $\mathrm{cp}=1$ is present with a high number in eutrophic environment, their presence indicates a less stable environment. Thus, the relationship between $\Sigma$ MI and $\Sigma$ MI2-5 on Figure 4 shows that the environment in the studied area is relatively stable.

The relationship among $\Sigma$ MI, PPI and MI on Figure 5 shows that LH2, LH4 and LH5 are three sampling points having PPI higher than MI very much. This proves that the maturity of the nematode community at these points were influenced by plant parasitic nematodes rather than free-living nematodes. The rates of $\mathrm{PPI} / \Sigma \mathrm{MI}$ at these points are very high (respectively $0.82,0.77$ and 0.86 ), this show that peppers in these points are infected parasitic nematodes seriously. The higher value of PPI compare to MI value demonstrates that the growth of nematode community in LH1 and LH3 is less influenced by plant parasitic nematode. Therefore, pepers at LH1 and LH3 are less infected parasitic nematodes than others. Ratio of PPI / $\Sigma$ MI reflects that infected parasitic level on target plants in study area was very high. It was an important ratio on assessing the impact of plant parasitic nematodes on pepper in particular and on other agricultural crops in general. From that the harmful effects of these parasites could be minimized.

\subsection{The relationship between trophic groups}
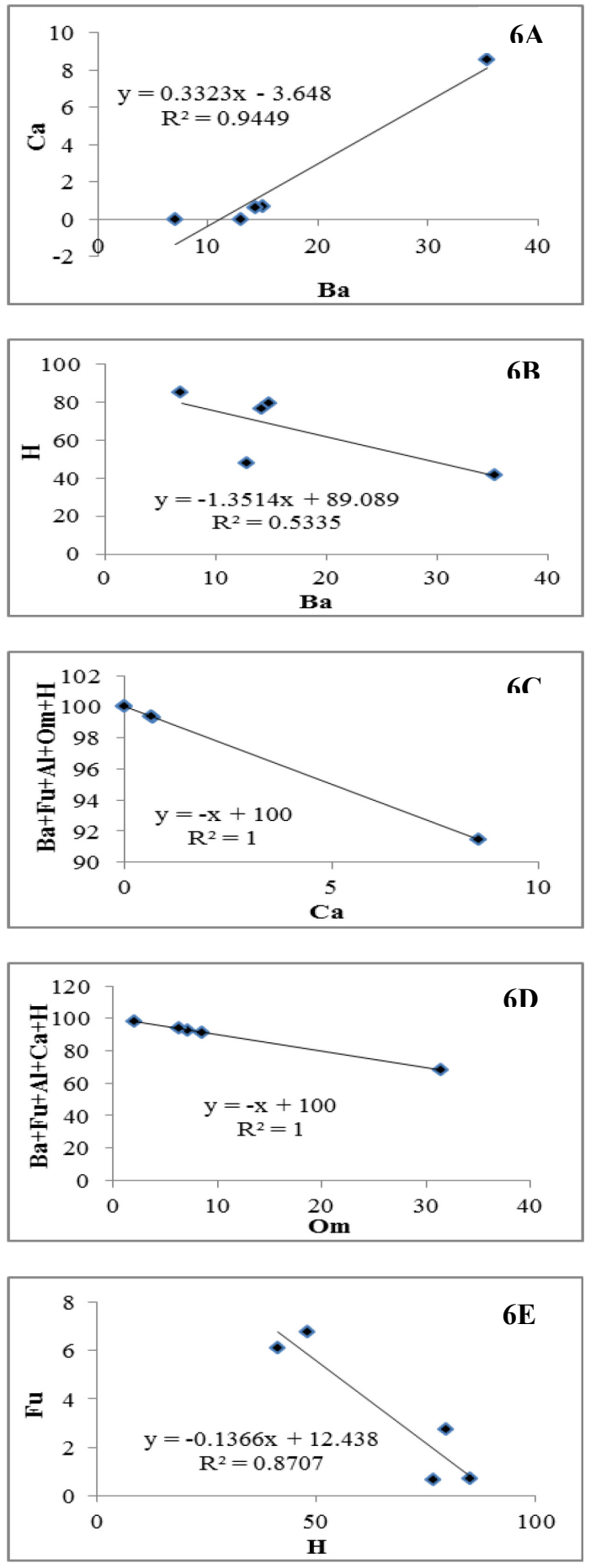

Figure 6. Relationship between trophic groups

Negative correlation was found between bacterivorous group and plant parasitic group $\left(\mathrm{R}^{2}=0.5335\right)$ (Figure 
$6 \mathrm{~B})$, plant parasitic group and fungivorous group $\left(\mathrm{R}^{2}=\right.$ 0.8707 ) (Figure $6 \mathrm{E})$, carnivorous group and others $\left(\mathrm{R}^{2}=\right.$ 1) (Figure 6C), omnivorous group and others $\left(R^{2}=1\right)$ (Figure 6D). The relationship between remaining trophic groups was negligible.

Carnivores and omnivores are two groups that had the most powerful influence on the rate of other groups. It could be seen in Figure 2, the sample that had high rate of carnivores and omnivores had rate of remaining groups lower than other points. Because they used other nematode groups as a food source, their presence would reduce rate of other groups. The negative correlation between omnivores and other groups is in agreement with the statement of Yeates et al. (1993) and Yeates (1999) that omnivore nematodes utilize a combination of hyphae, bacteria, microfaunal prey, diatoms and algae. Thus, an increase in the omnivore population will adversely affect the populations of other groups. These correlation results showed that in soil nematode community, trophic groups also influenced each other. So any external changes that made a certain nematode group increase or decrease leaded to the transformation of nematode related groups and changed nematode community structure. These changes reflected the current status of soil environment there.

\section{Conclusion}

This study gave a general background of the environmental status of studied area through the analysis of structural characteristics of nematode community. The result of study identified 30 genera belonging to six major trophic groups. Dominant trophic groups reflected the characteristics of pepper cultivation area. Research results also showed that pepper in the study was infected seriously with parasitic nematodes through assessing PPI and rate of PPI/ $/$ MI. Correlation analysis between trophic groups showed that trophic groups interacted closely and were sensitive to environmental factors. Therefore, nematodes are invertebrate animal groups having great potential in the use as biomarkers in evaluation of the soil environment quality.

\section{Acknowledgement}

The authors would like to thank the Institute of Tropical Biology at the Vietnam Academy of Science and Technology for the financial support of this study.

\section{References}

[1] Abebe, E., Andrássay, I., Schnell, S. 2007. Freshwater nematode - Ecology and Taxonomy. CABI publisher, USA. 772p.

[2] Cairns, J., McCormick, P.V., Niederlehner, B.R. 1993. A proposed framework for developing indicators of the ecosystem health. Hydrobiologia. 263(1), $44 \mathrm{p}$.

[3] Duong, D.H., Ngo, X.Q., Pham, M.D., Nguyen, V.T. 2009. Using nematode communities as a bio- indicator to assess the soil quality in An Thanh, Thuan An, Binh Duong province. Proceedings of the 3rd National Workshop on Ecology and Biological Resources, Hanoi, 1334-1340 (in Vietnamese).

[4] Ettema, C.H., Bongers, T. 1993. Characterization of nematode colonization and succession in disturbed soils using the Maturity Index. Biol. Fertil. Soils. 16: 79-85.

[5] Ferris, H., Venette, R.C., Lau, S.S. 1997. Population energetics of bacterial-feeding nematodes: carbon and nitrogen budgets. Soil Biol. Biochem. 29: 11831194.

[6] Freckman, D.W. 1988. Bacterivorous nematodes and organic matter decomposition. Agric. Ecosyst. Environ. 24: 195-217.

[7] Freckman, D.W., Ettema, C.H. 1993. Assessing nematode communities in agroecosystems of varying human intervention. Agric. Ecosyst. Environ. 45: $239-261$.

[8] Liang, W.J., Shuang, Z., Hua, J.F., Jiang, Y. 2007. Nematode Faunal Response to Grassland Degradation in Horqin Sandy Land. Pedosphere. 17: 611618.

[9] Nguyen, N.C., Nguyen, V.T. 2000. Fauna of Viet Nam - Plant parasitic nematodes. Publisher of Science and Technology. 400p (in Vietnamese).

[10] Nguyen, N.C., Vu, T.T. 2005. Application of terrestrial nematode community structure for assessing soil health in agricultural ecosystems. Proceedings of the $1^{\text {st }}$ National Workshop on Ecology and Biological Resources Hanoi. 690-697 (in Vietnamese).

[11] Nguyen, V.T. 2007. Fauna of Viet Nam - Free living nematodes. Publisher of Science and Technology. $455 \mathrm{p}$ (in Vietnamese).

[12] Nic, S. 2007. Lecture book of the Postgraduate International Nematology Course - General techniques. Ghent University. 38p.

[13] Randy, G., Anwar, L.B. 2004. Nematode behaviour. CABI Publisher. $445 \mathrm{p}$.

[14] Wasilewska, L. 1994. The effects of age of meadows on succession and diversity in soil nematode communities. Pedobiologia. 38: 1 - 11 .

[15] Yeates, G.W., Bird, A.F. 1994. Some observations on the influence of agricultural practices on the nematode faunae of some South Australian soils. Fund. Appl. Nematol. 17: 133 - 145.

[16] Yeates, G.W., Bardgett, R.D., Cook, R., Hobbs, P.J., Bowling, P.J., Potter, J.F. 1997. Faunal and microbial diversity in three welsh grassland soils under conventional and organic management regimes. J. Appl. Ecol. 34: 453 - 470.

[17] Yeates, G.W., Bongers, T., de Goede, R.G.M., Freckman, D.W., Georgieva, S.S. 1993a. Feeding habits in soil nematode families and genera. An outline for soil ecologists. J. Nematol. 25: 315 - 331 . 